\title{
Universiteit
}

Leiden

The Netherlands

\section{Theories of reputation}

Oster, J.S.; Koltay, A.; Wragg, P.

\section{Citation}

Oster, J. S. (2020). Theories of reputation. In A. Koltay \& P. Wragg (Eds.),

Research Handbooks in Comparative Law (pp. 48-64). Cheltenham: Edward Elgar. doi:10.4337/9781788970594.00010

Version:

License:

Downloaded from:
Publisher's Version

Licensed under Article 25fa Copyright Act/Law (Amendment Taverne)

https://hdl.handle.net/1887/3243916

Note: To cite this publication please use the final published version (if applicable). 


\title{
4. Theories of reputation
}

\author{
Jan Oster
}

\section{THE PURPOSE OF THEORY}

While defamation doctrine largely relates to the practical application of the law, reputation theory helps us to answer deeper 'why questions': Why does German defamation doctrine - at least to a certain extent - also protect the reputation of deceased persons, whereas English and US law does not? ${ }^{1}$ Why is harm to the reputation of a trading corporation not 'serious harm' within the meaning of Section 1(1) Defamation Act 2013, unless it has caused or is likely to cause the corporation serious financial loss? ${ }^{2}$ Why does German law also grant a cause of action for bilateral insult, whereas English defamation law requires a 'publication' of a defamatory statement to a third party? This contribution analyses reputation from the perspective of descriptive, not normative, theory. The chapter does not intend to justify existing legal doctrine or prescribe changes to the law, but rather aims at understanding, systematising and analysing the law of defamation and, to a lesser extent, privacy.

The contribution will first introduce two ideal-types of reputation theory - the argument from dignity and the argument from property - and will then propose a new conceptualisation of reputation, and its distinction from information privacy, with a view to the information that has been communicated. The contribution will conclude with a brief remark on the development of data protection as an increasingly important instrument for the protection of reputation.

\section{THEORETICAL FOUNDATIONS OF REPUTATION: TWO IDEAL-TYPES}

The law of defamation serves to protect a person's reputation. Despite that truism, the courts under investigation in this contribution - German and English courts, the US Supreme Court and the European Court of Human Rights (ECtHR) - have rarely ever expressly avowed themselves of a particular theoretical explanation for reputation. ${ }^{3}$ This judicial self-restraint strikingly contrasts with the courts' abundant reasoning on the rationales of defamation's natural antagonist: freedom of expression. ${ }^{4}$ It has therefore been left to academic scholars to identify

\footnotetext{
1 Although the law of defamation is not federal but state law in the US, for the sake of simplicity this contribution will refer to 'US law' in order to highlight the common traits of state defamation law, which is particularly due to the common origin in English law and the case law of the US Supreme Court.

See Defamation Act 2013, s 1(2).

3 An exception applies, in particular, to English case law of the nineteenth century, which will be referred to further below.

$4 \quad$ See only Handyside $v$ the United Kingdom App no 5493/72 (ECtHR, 7 December 1976), [49]; 1 BvR 400/51 [1958] BVerfGE 7, 198, 207; Gertz v Robert Welch, Inc. 418 US 323, 339-40 (1974); $R v$ Secretary of State for the Home Department, ex $p$ Simms [2000] 2 AC 115. For further references, see
} 
the foundations of reputation. To name but a few: Robert C. Post names 'honor, property and dignity' as 'concepts of reputation'; Lawrence McNamara refers to the 'social judgment of the person based upon facts which are considered relevant by a community'; ${ }^{6}$ similarly, in a book that has been frequently referred to by German courts, the German scholar Ernst Helle emphasises 'public opinion'; ' David Rolph conceptualises reputation as 'celebrity'; ${ }^{8}$ and David S. Ardia regards reputation as 'part of a complex set of feedback mechanisms'. ${ }^{9}$ This contribution cannot engage with all these approaches in detail. However, on a higher level of abstraction, two conceptual lines can be identified: theories which define reputation from the judgment of a third party, and those which see reputation as an intrinsic value of a human being.

The first theoretical line, which is more prevalent in English-speaking scholarship, will henceforth be named 'reputation as property'. The second line, which is strongly discernible in German scholarship and even legislation, will be named 'reputation as honour and dignity'. It has to be emphasised from the outset that these two lines are mere ideal-types in a Weberian sense; judicial practice does not reflect them in as clear-cut a way as they might appear under the clinical conditions of a book contribution. ${ }^{10}$ In particular, it would be inaccurate to state, for example, that English and US courts protect reputation 'as property', whereas for German courts and the ECtHR reputation is identical with honour and dignity. This notwithstanding, although the US Supreme Court, ${ }^{11}$ on the one hand, and the House of Lords, ${ }^{12}$ on the other, referred from time to time to reputation as being anchored in human dignity, the argument from human dignity never received the same significance in English and US case law as it did in Germany and under the case law of the ECtHR. ${ }^{13}$ By contrast, the Anglo-American understanding of reputation is more informed by the liberal argument from property. ${ }^{14}$ Despite some risk of oversimplification, these two ideal-types thus enable us to understand how

Eric Barendt, Freedom of Speech (2nd edn, OUP 2005), 1 ff; András Koltay, Freedom of Speech: The Unreachable Mirage (Wolters Kluwer 2013), 3 ff; Jan Oster, Media Freedom as a Fundamental Right (CUP 2015), 13 ff; Jan Oster, European and International Media Law (CUP 2017), 39 ff.

5 Robert C Post, 'The Social Foundations of Defamation Law: Reputation and the Constitution' (1986) 74 California Law Review 691, 693.

6 Lawrence McNamara, Reputation and Defamation (OUP 2007), $21 \mathrm{ff}, 37 \mathrm{ff}$.

7 Ernst Helle, Der Schutz der Persönlichkeit, der Ehre und des wirtschaftlichen Rufs im Privatrecht (2nd edn, Mohr Siebeck 1969), 8.

8 David Rolph, Reputation, Celebrity and Defamation Law (Ashgate 2008), $178 \mathrm{ff}$.

9 David S Ardia, 'Reputation in a Networked World: Revisiting the Social Foundations of Defamation Law' (2010) 45 Harvard Civil Rights - Civil Liberties Law Review 261, 263 ff.

${ }_{10}$ On the limits of philosophical underpinnings of legal doctrine in general, see Ronald Dworkin, Taking Rights Seriously (Duckworth 1977), 134; on the limits of theories of reputation in particular, see McNamara, supra note 6, 38 .

${ }_{11}$ Rosenblatt v Baer 383 US 75, 92 (1966) (concurring opinion Steward J); Gertz v Robert Welch supra note 4, 341; Dun and Bradstreet, Inc. v Greenmoss Builders, Inc. 472 US 749, 758 (1985).

12 Reynolds $v$ Times Newspapers Ltd [2001] 2 AC 127, 201.

13 Compare Post, supra note 5, 735; James Q Whitman, 'The Two Western Cultures of Privacy: Dignity Versus Liberty' (2004) 113 Yale Law Journal 1151; Cristopher McCrudden, 'Human Dignity and Judicial Interpretation of Human Rights' (2008) 19 The European Journal of International Law 655, 704; Hannes Rösler, 'Dignitarian Posthumous Personality Rights: An Analysis of US and German Constitutional and Tort Law' (2006) 26 Berkeley Journal of International Law 153, 173; Luís R Barroso, 'Here, There, and Everywhere: Human Dignity in Contemporary Law and in the Transnational Discourse' (2012) 35 Boston College International \& Comparative Law Review 331.

14 Compare Post, supra note 5, 727; Rösler, supra note 13, 162. 
English, US and German courts, as well as the ECtHR, conceptualise reputation, and they help us to provide answers for 'why questions' with an efficient balance between simplicity and explanatory force.

\subsection{The Argument from Dignity}

The understanding of reputation as (an aspect of) honour and dignity is deeply rooted in German scholarship, case law and even legislation. Human dignity, which is protected in absolute terms ('inviolable'), lies at the heart of fundamental rights protection under the German Constitution, the Basic Law. The protection of human dignity is enshrined in the very first article of the Basic Law, and it underlies the protection of all other fundamental rights codified in the Basic Law. ${ }^{15}$ The protection of human dignity has prompted German courts to develop a protection of 'personality rights' beyond the actual text of the Constitution. ${ }^{16}$ Those personality rights include, for example, the right to privacy, the right to protection of one's image, the right to protection of one's personal data - and personal honour. Yet it should be emphasised that personality rights are not identical with human dignity. They are rooted in human dignity, but they do not share dignity's aura of absolute 'inviolability'. In other words, interferences with personality rights can be justified, whereas interferences with human dignity cannot. ${ }^{17}$ However, the closer a personality right is situated to the dignitarian core of any right, the more difficult it is to justify an interference. Examples for such interferences would be revelations of intimate information or abusive insults. ${ }^{18}$

Moving from the constitutional to the statutory perspective, a useful demonstration of the German conceptualisation of honour can be found in Sections 185 to 187 German Criminal Law Code. These provisions are relevant beyond the confines of criminal law, because Section 823(2) of the Civil Law Code grants a private law claim to anyone injured by a violation of, inter alia, Sections 185 to 187 Criminal Law Code. Section 186 punishes for defamatory statements of fact about a third person that the defendant cannot prove to be true. Section 187 Criminal Law Code is an aggravated offence; it penalises defamatory statements of fact about a third person that the defendant knows to be false. Read in conjunction with Section 823(2) Civil Law Code, Sections 186 and 187 are thus functionally equivalent to the tort of defamation under English and US law. For comparative purposes, the most interesting provision is thus Section 185 Criminal Law Code. The offence committed under Section 185 consists of one single word: 'insult'. The concept of 'insult' essentially contains the forms of communication that are not covered by Sections 186 and 187. First is the communication of derogatory opinion (as opposed to facts) to third persons; this is still equivalent to the English and US law of defamation. Second, however, the concept of 'insult' also covers the communication of derogatory opinions and defamatory facts to the claimant himself or herself. Therein lies a major difference from the Anglo-American law of defamation, which requires the communication ('publication') of the defamatory statement to a third party. In German

1 BvR 426/02 [2003] BVerfGE 107, 275, 284. This can be inferred from Basic Law, art 1(2).

161 BvR 1168/04 [2006] NJW 2006, 3409, 3410; 1 BvR 1783/05 [2007] BVerfGE 119, 1, 29; 1 BvR 1891/05 [2010] NJW-RR 2010, 1195, [33]. The civil law personality right is slightly distinct from the constitutional law: I ZR 151/56 [1958] BGHZ 26, 349, 254; I ZR 44/66 [1968] BGHZ 50, 133, 143 f.

171 BvR 932/94 [2001] NJW 2001, 2957, 2959.

18 See, in particular, 1 BvR 313/85 [1987] BVerfGE 75, 369, $379 \mathrm{f}$. 
legal scholarship, Sections 185 to 187 German Criminal Law Code are thus not treated as 'crimes against reputation', but as 'crimes against honour'. ${ }^{19}$ Only insofar as these provisions require communication of information to a third party, which is the case under Sections 186 and 187 and partly also under Section 185, is the protected interest reputation as a subcategory of honour, the so-called outer honour. By contrast, insofar as Section 185 also penalises the communication of defamatory facts or opinion to the victim himself or herself, the protected interest is called the person's 'inner honour', which can be roughly translated as self-esteem.

Against this constitutional and statutory backdrop, it is deeply engraved in the German legal mindset to think reputation from honour, and to think honour from dignity. From a theoretical standpoint, the argument from dignity charges the concept of honour - and thus of reputation - with some 300 years of German philosophy, at the very least. ${ }^{20}$ In particular, the works of Immanuel Kant warrant attention. He underlined the significance of reason and moral autonomy for human dignity. With a view to reputation in particular, Kant distinguished between esteem by others and human dignity; the latter has a value, but not a price. In particular, human dignity entails that a human being must always be an end in himself or herself, but never a means to an end. ${ }^{21} \mathrm{~A}$ theory of honour (and reputation) that derives from human dignity must thus treat honour and reputation as an intrinsic value; a human being has honour because he or she is a human being. Honour cannot be earned, lost or sold. ${ }^{22}$

One cannot but emphasise that Kantian philosophy and subsequent German Idealism added much more complexity to the notions of dignity, honour and reputation than this brief introduction can possibly cover. ${ }^{23}$ Nevertheless, the explanatory force of a theory of reputation from honour and dignity allows for several explanations even upon such a simplified reflection. First, the argument from human dignity calls for protection of a person's esteem by others, because a human being is an end in their own right and must not be treated as a means to an end, for example, by making them subject to ridicule. This idea is reflected in Sections 186 and 187 Criminal Law Code as well as in Section 185 Criminal Law Code, insofar as the latter provision also penalises the dissemination of insulting statements of opinion. Second, the argument from human dignity necessarily requires protection of a person's self-esteem, their 'inner honour'; this is done by Section 185 Criminal Law Code. Third, the argument from human dignity explains why German courts, at least to a certain extent, also protect the reputation of deceased persons: the obligation of the state to protect a person's human dignity (Article 1(1)2 Basic Law) does not end with a person's death. ${ }^{24}$ An attack on a deceased

19 See only Johannes Wessels, Michael Hettinger and Armin Engländer, Strafrecht Besonderer Teil 1 (41st edn, CF Müller 2017), ch 5.

${ }_{20}$ The notion of dignity (dignitas) can be traced back at least to Marcus Tullius Cicero, De officiis (first published $44 \mathrm{BC}$ ) First book, 5(15) ff, whereas the distinction between 'outer' honour and the intrinsic good can already be found in Aristotle, Nicomachean Ethics, I, 1095b22-27.

${ }_{21}$ Immanuel Kant, Die Metaphysik der Sitten (first published 1797, Suhrkamp 2014), $600 \mathrm{f}$.

22 Compare Eric Descheemaeker, 'Protecting Reputation: Defamation and Negligence' (2009) 29(4) Oxford Journal of Legal Studies 603, 609; Luciano Floridi, 'On Human Dignity as a Foundation for the Right to Privacy’ (2016) 29 Philosophy \& Technology 307 (on privacy).

${ }_{23}$ See, for example, Georg WF Hegel, Vorlesungen über die Ästhetik (first published 1835-8), 630; Georg WF Hegel, Grundlinien der Philosophie des Rechts (first published 1820), § 206; Arthur Schopenhauer, Parerga und Paralipomena I (first published 1851, Haffmanns 1988), 361. From pre-Kantian philosophy, see Samuel Pufendorf, De iure naturae et gentium libri octo (first published 1672), Second book, ch $1 \S 5$.

${ }^{24} 1$ BvR 435/68 [1971] BVerfGE 30, 173, 194; 1 BvR 2707/95 [2000] NJW 2001, 594. 
person's reputation that amounts to a violation of that person's dignity entitles the deceased's family or other representatives to request an injunction..$^{25}$ In this context, one has to remember that although honour is an aspect of human dignity, it is not identical with it. Not every attack on a person's honour amounts to a violation of human dignity. The latter requires, according to the German Federal Constitutional Court, a 'debasement, stigmatisation, ostracism or vilification' that goes beyond mere defamation. ${ }^{26}$

Similarly, the ECtHR has also held that Article 8 European Convention of Human Rights (ECHR) may, depending on the circumstances, ${ }^{27}$ grant a postmortal right to respect for private life. ${ }^{28}$ This case law can only be explained with the notion of 'private life' as an aspect of human dignity. It is thus not surprising that references to the dignitarian aspect of reputation can also be found in the case law of the ECtHR. In Cumpănă und Mazăre v Romania, the Strasbourg Court referred to the proximity of reputation and dignity, albeit only in passing: 'the Romanian courts fully recognised that it involved a conflict between the applicants' right, as representatives of the media, to impart information and ideas and Mrs R.M.'s right to protection of her reputation and dignity. ${ }^{29}$ Loucaides J was more explicit in his concurring opinion to Lindon, Otchakovsky-Laurens and July v France, when he wrote:

The suppression of untrue defamatory statements, apart from protecting the dignity of individuals, discourages false speech ... And although [the mass media] may be achieving such objectives incidentally, accidentally or occasionally, even deliberately, they should be subject to certain restraint out of respect for the truth and for the dignity of individuals. ${ }^{30}$

To be sure, in the 2009 decision Karakó v Hungary, the Court distinguished between 'personal integrity and reputation, the two being protected in different legal ways', whereby 'reputation has traditionally been protected by the law of defamation as a matter related primarily to financial interests or social status' ${ }^{31}$ Reputation may only be deemed to be encompassed by the right to respect for private life (Article 8(1) ECHR) 'under exceptional circumstances', particularly when 'the factual allegations were of such a seriously offensive nature that their publication had an inevitable direct effect on the applicant's private life'. ${ }^{32}$ However, this rather sharp distinction between reputation, on the one side, and personal integrity, on the other side, was not consistent with previous and subsequent case law. ${ }^{33}$ In Radio France v France, the Court had already established that the protection of one's reputation is one of the rights guaranteed

25 But not pecuniary damages; see I ZR 266/52 [1954] BGHZ 15, 249, 259 f; VI ZR 246/12 [2014] NJW 2014, 2871; Rösler, supra note 13, 184.

26 See, for example, 1 BvR 435/68 [1971] BVerfGE 30, 173, 194; 1 BvR 932/94 [2001] NJW 2001, 2957, 2958; VI ZR 244/07 [2008] NJW 2009, 751, [16].

${ }_{27}$ In particular, the lapse of time between the death and the impugned communication about the deceased (see Editions Plon v France App no 58148/00 (ECtHR, 18 May 2004), [47] and [53]).

28 Compare ibid [34] and Armoniené v Lithuania App no 36919/02 (ECtHR, 25 November 2008), [43] (concerning information privacy); Genner v Austria App no 55495/08 (ECtHR, 12 January 2016), [35] (concerning reputation); Sinkova v Ukraine App no 39496/11 (ECtHR, 27 February 2018), [103] and [110] (concerning honour).

${ }_{29}$ Cumpănă and Mazăre v Romania App no 33348/96 (ECtHR, 17 December 2004), [109].

30 Lindon, Otchakovsky-Laurens and July v France App nos 21279/02 and 36448/02 (ECtHR, 22 October 2007), concurring opinion Loucaides J.

31 Karakó v Hungary App no 39311/05 (ECtHR, 28 April 2009), [22].

32 Ibid [23].

33 See Oster, supra note 4, 149-50. 
by Article 8 ECHR as one element of the right to respect for private life. ${ }^{34}$ The Court explained in Pfeifer $v$ Austria and reiterated in Petrina $v$ Romania that 'a person's reputation ... forms part of his or her personal identity and psychological integrity and therefore also falls within the scope of his or her "private life", ${ }^{35}$ An individual's reputation and honour are thus not only protected as defensive rights against free speech, ${ }^{36}$ as Article 10(2) ECHR suggests. ${ }^{37}$ Rather, they have their own value as fundamental rights, namely as characteristics of the right to respect for private life as guaranteed in Article 8(1) ECHR. In the 2012 decision Axel Springer $A G v$ Germany (No 1), the Grand Chamber of the Court alleviated the strict Karakó requirements for reputation to fall under Article 8(1) ECHR - most notably, without even citing the Karakó decision. ${ }^{38}$ The Court merely required that 'an attack on a person's reputation must attain a certain level of seriousness' in order for Article 8 ECHR to come into play. ${ }^{39}$ Although the Convention States in their preparation of the ECHR deleted the words 'nor to attacks upon his honour and reputation' from Article $8 \mathrm{ECHR},{ }^{40}$ the right to respect for one's reputation can now be regarded as a subcategory to the dignitarian right to respect for private life. ${ }^{41}$ Article 8 ECHR is thus similar to Article 12 Universal Declaration of Human Rights and Article 17 ICCPR, according to which no one shall be subjected to unlawful attacks on his or her honour and reputation, and everyone has the right to the protection of the law against such attacks.

While the argument from human dignity may thus explain various aspects of German and ECtHR case law on the protection of honour and reputation, it fails to explicate other phenomena. In particular, the notion of human dignity cannot explain why German courts - and the ECtHR - also protect the reputation of trading corporations. ${ }^{42}$ This can only be explained with the second ideal-type of reputation theories: the argument from property.

\subsection{The Argument from Property}

According to the argument from human dignity, honour and reputation are intrinsic values qua being human. By contrast, a diametrically opposed line of argument posits that honour and reputation are values that are only conceivable in relation to, and due to social interaction with, other human beings. Honour and reputation can be earned, increased and lost. They are

\footnotetext{
34 Radio France and Others v France App no 53984/00 (ECtHR, 30 March 2004), [31].

35 Pfeifer v Austria App no 12556/03 (ECtHR, 15 November 2007), [35]; Petrina v Romania App no 78060/01 (ECtHR, 14 October 2008), [29].

36 A v Norway App no 28070/06 (ECtHR, 9 April 2009), [64].

37 For this approach, see Douglas v Hello! [2001] QB 967, CA 1003, [136]; Berezovski v Forbes, Inc. (No 2) [2001] EWCA Civ 1251, [11].

38 Axel Springer AG v Germany (No 1) App no 39954/08 (ECtHR, 7 February 2012), [83].

39 Ibid (emphasis added); confirmed in Tănăsoaica v Romania App no 3490/03 (ECtHR, 19 June 2012), [37] and Lavric v Romania App no 22231/05 (ECtHR, 14 January 2014), [31]: 'a certain level of gravity'.

40 Council of Europe, 'Preparatory Work on Article 8 of the European Convention on Human Rights' DH (56) $12,5$.

${ }_{41}$ On reputation, see Radio France and Others v France supra note 34, [31]; Print Zeitungsverlag GmbH v Austria App no 26547/07 (ECtHR, 10 October 2013), [31]. On honour, see Polanco Torres et Movilla Polanco v Spain App no 34147/06 (ECtHR, 21 September 2010), [40]; A v Norway supra note 36, [64].

${ }_{42}$ See Civil Law Code, s 824; 1 BvR 2566/95 [2004] NJW-RR 2004, 1710, 1712; VI ZR 39/14 [2014] NJW 2015, 773, [13].
} 
thus distinct from Kantian human dignity, and more comparable with the Lockean concept of property. ${ }^{43}$ Accordingly, every individual human being 'has a property in his [or her] own person'. Therefore, the 'labour of his [or her] body and the work of his [or her] hands' are theirs. ${ }^{44}$ Transferred to the idea of reputation as property, this approach does thus not emphasise the dignitarian aspect of reputation (or honour), but its social and, in particular, economic value. ${ }^{45}$ The value of reputation follows from its estimation by others. Reputation as property can thus only be based on esteem by others, not self-esteem. The most radical expression of this approach is apparently to be found in Thomas Hobbes' Leviathan:

The value or worth of a man is, as of all other things, his price; that is to say, so much as would be given for the use of his power, and therefore is not absolute, but a thing dependent on the need and judgement of another ... And as in other things, so in men, not the seller, but the buyer determines the price. For let a man, as most men do, rate themselves at the highest value they can, yet their true value is no more than it is esteemed by others. The manifestation of the value we set on one another is that which is commonly called honouring and dishonouring. To value a man at a high rate is to honour him; at a low rate is to dishonour him. ${ }^{46}$

In legal practice, the argument from property found its zenith in English case law of the nineteenth century, where courts expressly equated reputation with property. ${ }^{47}$ One may surmise that social circumstances exerted a major influence on legal thinking here. ${ }^{48}$ The conception of reputation as property - or, in the terminology of Pierre Bourdieu, as 'social capital'49 suggests a social structure in which human beings are connected with each other through a marketplace..$^{50}$ Accordingly, the loss of reputation is susceptible to measurement just as the loss of property or money. ${ }^{51}$ This would explain why the tort of defamation requires 'publication' of a defamatory statement to a third person and, unlike German law, does not cover bilateral insult: cases of merely bilateral communication lack the social connection on which the 'value' of reputation is founded.

\subsection{Doctrinal Consequences of the Argument from Dignity and the Argument from Property - Divergencies and Overlaps}

By contrast to the argument from dignity, the argument from property can flawlessly explain the protection of a trading corporation's reputation..$^{52}$ Just as a legal entity can possess

\footnotetext{
43 Compare Post, supra note 5, 691, 694 ff; Ardia, supra note 9, $267 \mathrm{ff}$.

44 John Locke, Second Treatise on Government (first published 1690), ch V, [27].

45 See Gregory S Alexander, 'Property as a Fundamental Constitutional Right: The German Example' (2003) 88 Cornell Law Review 733, 739.

46 Thomas Hobbes, Leviathan (first published 1651, McMaster University Archive of the History of Economic Thought), 54-5.

47 M'Pherson v Daniels (1829) 10 B \& C 263, 276; Metropolitan Saloon Omnibus Co v Hawkins [1859] 4 H \& N 87, 90; Dixon v Holden (1868-9) LR 7 Eq 488.

48 Compare Rolph, supra note 8, 22.

49 Pierre Bourdieu, 'The Social Space and the Genesis of Groups' (1985) 14 Theory and Society 723.

50 Post, supra note 5, 695; Dario Milo, Defamation and Freedom of Speech (OUP 2009), 27; David

Howarth, 'Libel: Its Purpose and Reform' (2011) 74 Modern Law Review 845, 853.

51 Compare Milo, supra note 50, 27 (on reputation).

52 See Defamation Act 2013, s 1(2); South Hetton Coal Co. Ltd v North-Eastern News Association Ltd [1894] 1 QB 133; Derbyshire County Council v Times Newspapers Ltd [1992] QB 770; Jameel v
} 
property - this is expressly recognised in Article 1 First Protocol to the ECHR - it can have a reputation..$^{53}$ The reputation of a trading corporation is of a purely commercial nature; like its property, its 'good name' is an economic asset. ${ }^{54}$ By contrast, a trading corporation does not have a dignity comparable to human beings. ${ }^{55}$ In particular, a company does not participate in the dignity of its employees; instead, the reputation of a company and the honour and dignity of its employees need to be strictly separated. ${ }^{56}$ As a result, the protection of a company's reputation is not rooted in the anthropocentric right to respect for private life but in Article 1(1) First Protocol ECHR. ${ }^{57}$

In turn, based on the argument from property, the tort of defamation would not protect a deceased person's reputation, just as a deceased person cannot have property anymore. And this does indeed correspond to the law of both England and Wales and the United States (US)..$^{58}$ Furthermore, the argument from property has no difficulty in explaining that defamation - just as the damage or destruction of a person's property - leads to pecuniary compensation. This is different with the argument from human dignity: as human dignity is inalienable, harm to reputation cannot be measured in monetary terms and can thus not be subject to financial compensation. In short, honour must not be 'commercialised'. ${ }^{59}$ As a consequence, German law prioritises nonpecuniary remedies, such as injunctions, corrections and a right of reply, and grants pecuniary compensation only under narrow circumstances. ${ }^{60}$ This is very different from the Anglo-American approach, where pecuniary damages are the primary remedy. In England and Wales, an 'offer to make amends' can only constitute a defence against a defamation claim, ${ }^{61}$ and a right of reply to inaccuracies is provided for merely under press self-regulation. ${ }^{62}$ In Miami Herald $v$ Tornillo, the US Supreme Court even declared a statutory obligation to publish replies incompatible with the First Amendment. ${ }^{63}$ To be sure, this difference between

Wall Street Journal Europe Sprl [2006] UKHL 44; Dun and Bradstreet, Inc., v Greenmoss Builders, Inc. 472 US 749, 762 (1985); Martin Marietta Corp. v Evening Star Newspaper Co. 417 FSupp 947, 955 (DDC 1976).

53 Jan Oster, 'The Criticism of Trading Corporations and Their Right to Sue for Defamation' (2011) 2 Journal of European Tort Law 255.

${ }_{54}$ Compare Derbyshire CC v Times Newspapers Ltd [1993] AC 534, 547; Jameel v Wall Street Journal Europe Sprl [2006] UKHL 44 [24]; Milo, supra note 50, 27.

55 Compare Uj v Hungary App no 23954/10 (ECtHR, 19 July 2011), [22]; Kharlamov v Russia App no 27447/07 (ECtHR, 8 October 2015), [29]; Rubber Improvement v Daily Telegraph [1964] AC 234, 262; Jameel v Wall Street Journal Europe Sprl [2006] UKHL 44, [91] (Lord Hoffmann), [154] (Baroness Hale); Martin Marietta Corp. v Evening Star Newspaper Co. 417 FSupp 947, 955 (DDC 1976).

${ }_{56}$ See Jameel v Wall Street Journal Europe Sprl [2006] UKHL 44, [18].

57 Oster, supra note 53, 255; by contrast, see David J Acheson, 'Corporate Reputation under the European Convention on Human Rights' (2018) 10 Journal of Media Law 49. The question has been left open by the ECtHR in Firma EDV für Sie, EFS Elektronische Datenverarbeitung Diensteilsungs GmbH v Germany App no 32783/08 (ECtHR, 2 September 2014), [23].

58 See Rose v Daily Mirror, Inc. 31 NE2d 182 (NY 1940); Restatement (Second) of Torts $\S 560$ (1977); Rösler, supra note 53, 185. See also GJ Pitt, 'Report of the Committee on Defamation' (1976) 39(2) Modern Law Review 187, 195.

59 1 BvR 112/65 [1973] BVerfGE 34, 269, 286; compare VI ZR 259/60 [1961] BGHZ 35, 363, 369.

60 Compare VI ZR 259/60 [1961] BGHZ 35, 363, 369; VI ZR 246/74 [1976] NJW 1976, 1198, 1201;

1 BvR 112/65 [1973] BVerfGE 34, 269, 286.

${ }_{61}$ See Defamation Act 1996, ss 2-4.

62 See IPSO Editors' Code of Conduct, art 1(3).

63 Miami Herald $v$ Tornillo 418 US 241 (1974). 
Germany, on the one side, and England and Wales, as well as the US, on the other cannot be explained exclusively by reference to the underlying theories of reputation; in particular, the aversion against a right of reply also has a foundation in different conceptions of free speech. ${ }^{64}$ Against this backdrop, the Council of Europe decided not to include a right to reply in Article 10 ECHR but left it to the discretion of the Convention States to provide for such a right. ${ }^{65}$ However, the different conceptions of reputation do at least contribute to understanding the divergent judicial approaches.

Nevertheless, the argument from dignity and the argument from property do not necessarily induce different doctrinal consequences. Both theoretical explanations are, at their core, individualistic; as a consequence, neither theory would justify the protection of the honour or reputation of a community, such as a notion of 'family honour', ${ }^{66}$ 'religious honour' ${ }^{67}$ or 'national honour'. ${ }^{68}$ Moreover, both theories are egalitarian: they apply to all human beings alike, be it by virtue of being human (dignity), or by virtue of merits and achievements (property). In turn, no person has more honour and reputation than another person only by virtue of birthright, gender, ${ }^{69}$ ethnic or national background. Furthermore, both theories explain reputation merely as a status right, but not as a liberty: reputation limits the liberties of others, particularly freedom of expression, but it does not grant liberties in its own right, such as a right (or even a duty) to defend one's reputation in a duel.

\section{REPUTATION AND INFORMATION}

Thus far, scholarly research has mainly focused on reputation from the inside perspective, that is attempting to find a definition of, and rationales for, the protection of reputation. Based on

64 Barendt, supra note 4, 425; Oster, supra note 4, 79; compare Saliyev v Russia App no 35016/03 (ECtHR, 21 October 2010), [54]; 1 BvR 967/05 [2007] NJW 2008, 1654, [26].

${ }_{65}$ Council of Europe, 'Preparatory work on art 10 of the European Convention on Human Rights' DH (56) 15, 5; Winer $v$ the United Kingdom App no 10871/84 (1986) 48 DR 154, EComHR, [3]. The case-law of the ECtHR is not yet entirely clear on this point, although the Court has a tendency to infer a right of reply from ECHR, arts 8 and 10: Melnychuk $v$ Ukraine App no 28743/03 (ECtHR, 21 November 2013); Vitrenko and Others v Ukraine App no 23510/02 (ECtHR, 16 December 2008); Kaperzyński v Poland App no 43206/07 (ECtHR, 3 April 2012); Eker v Turkey App no 24016/05 (ECtHR, 24 October 2017), [45]; Ronan Ó Fathaigh, 'The Recognition of a Right of Reply under the European Convention' (2012) 4 Journal of Media Law 322, 327; Koltay, supra note 4, 199 ff.

${ }_{66}$ Compare Putistin v Ukraine App no 16882/03 (ECtHR, 21 February 2014), [37 f]; VI ZR 68/73 [1974] GRUR 1974, 797.

${ }_{67}$ See Jeroen Temperman, 'Blasphemy, Defamation of Religions and Human Rights Law' (2008) 26 Netherlands Quarterly of Human Rights 517, 526; Marloes van Noorloos, 'Criminalising Defamation of Religion and Belief' (2014) 22 European Journal of Crime, Criminal Law and Criminal Justice 351 and 356; Jan Oster, 'Religiously Offensive Speech: A Doctrinal Inquiry' (2016) 12 Review of International Law \& Politics 139.

68 See IX ZB 10/18 [2018] NJW 2018, 3254, where the Court rejected the recognition of a Polish judgment that, inter alia, protected 'national honour'.

69 That was different in a decision of the German Federal Court of Justice from 1963, in which the Court expressly referred to the 'woman's honour' (Frauenehre) of a defamed female TV presenter (VI ZR 55/62 [1963] BGHZ 39, 124, 128). In the UK, it was only in 2013 that the Victorian Slander of Women Act 1891 (54 \& 55 Vict. c. 51) was repealed (Defamation Act 2013, s 14(1)). 
previous work, ${ }^{70}$ this section suggests an alternative approach from the outside perspective: rather than asking inductively what reputation is and what its theoretical foundations are, this approach inquires deductively when reputation is being interfered with.

Reputation is interfered with by the dissemination of certain information. A theory of (an interference with) reputation can thus be based on a taxonomy of that information. Thus conceptualised, reputation can be understood as a right to control information about oneself. Law categorises and evaluates communication and its content: information. Communication can contain 'incitement to hatred', a 'statement on a matter of public interest', a 'false representation', and many more; information can be, for example, 'public', 'confidential', 'secret', private', 'inaccurate' or 'intimate'. The tort of defamation makes no exception: it applies if a statement is 'defamatory', and this is only the case if it is either 'untrue'71 or at least not 'substantially true', ${ }^{72}$ or if it constitutes a derogatory 'opinion'.${ }^{73}$ In turn, it is a defence to an action for defamation for the defendant to show that the imputation conveyed by the statement complained of is substantially true (Section 2(1) Defamation Act 2013). In such cases, the law of privacy may apply. Against this backdrop, the following 'taxonomy of information' applies:

- Category I Statements of fact:

- true statements of fact;

- $\quad$ statements that are untrue and which the publisher knew to be untrue;

- $\quad$ statements that the publisher believed to be true when issued, but which later turned out to be untrue; and

- $\quad$ statements that have neither been proven true nor untrue;

- Category II Statements of opinion.

The taxonomy of information thus requires distinguishing between statements of fact and statements of opinion. The general formula for that distinction is that statements of fact are susceptible of proof, ${ }^{74}$ whereas statements of opinion - alternatively: 'value judgments' or 'ideas' - concern thoughts which are not susceptible of proof. ${ }^{75}$ The taxonomy of information is thus based on the assumption that it is possible to distinguish between statements of fact and of opinion. Postmodern discourse challenges that possibility; this happens, most interestingly, on both ends of the political spectrum in quite similar ways: while one camp propagates cultural and epistemological relativism, the other camp openly professes the existence of 'alternative facts'. And indeed, whether 'the truth' exists and what 'the truth' is belong to one of the oldest questions of philosophy. ${ }^{76}$ Sceptical schools have questioned the epistemological

See Oster, supra note 4, $167 \mathrm{ff}$; Oster, supra note 4, $17 \mathrm{f}$.

$71 \quad$ See German Criminal Law Code, s 187.

72 Defamation Act 2013, s 2(1); compare German Criminal Law Code, s 186.

73 Defamation Act 2013, s 3; German Criminal Law Code, s 185.

74 See, for example, Dyuldin and Kislov v Russia App no 25968/02 (ECtHR, 31 July 2007), [46]; OOO Ivpress and Others $v$ Russia App nos 33501/04, 38608/04, 35258/05 and 35618/05 (ECtHR, 22 January 2013), [72]; VI ZR 174/72 [1974] MDR 1974, 921.

${ }_{75}$ See, for example, Dyuldin and Kislov v Russia supra note 74, [46]; OOO Ivpress and Others $v$ Russia, supra note 74, [72]; 1 BvR 671/70 [1976] BVerfGE 42, 143, 149.

76 Compare Aristotle, Metaphysics, 993a30 ff; Immanuel Kant, Kritik der reinen Vernunft (first published 1781, Suhrkamp 2014), 102; Ludwig Wittgenstein, Tractatus Logico-Philosophicus (first published 1922), 1.1, 2.04-06, 2.222-225, 4.063. 
possibility of distinguishing between 'true' and 'untrue' statements. ${ }^{77}$ Nevertheless, at least for the purposes of the law, the dichotomy between statements of fact and statements of opinion can and should be upheld.

First, the law itself is based on the assumption that the proof of truth or untruth is possible; examples are the crimes of fraud and of perjury and the tort of defamation. Second, it is not the purpose of the law to establish 'the truth' in a philosophical sense that would convince even a scepticist; instead, the law requires ascertaining whether a certain statement corresponds with empirical reality, and thus presupposes the Aristotelian correspondence theory. ${ }^{78}$ Third, a statement is to be considered 'true' under the law if a court finds that this is the case. As a result, the law presupposes the existence of a final arbiter that operates on the basis of rules of procedure and burden of proof. This arbiter is lacking in philosophy.

To be sure, the distinction between statements of fact and statements of opinion can at times be difficult to draw. ${ }^{79}$ This is the case, for example, with rhetorical questions, ${ }^{80}$ innuendo, ${ }^{81}$ statements of fact that are disguised as opinions ('in my opinion, it was X who committed the crime') ${ }^{82}$ and the use of legal terminology by nonlawyers ('all soldiers are murderers'). ${ }^{83}$ However, over the course of time, courts in all jurisdictions under consideration have established workable - not always identical, but at times remarkably similar - principles that enable them to decode such language and establish its meaning for the purposes of a legal assessment. ${ }^{84}$

If a statement is to be considered a statement of fact, then the most important factor relevant to the balancing exercise between freedom of expression and conflicting rights is the authenticity of the information disclosed. Therefore, a distinction must be drawn between statements of fact that are proven true, statements that are proven untrue and statements the truth of which could not be established. If the defendant can prove the statement to be true, then a claim

77 See C Edwin Baker, 'Scope of the First Amendment Freedom of Speech' (1978) 25 UCLA Law Review 964, 974 f; Stanley Ingber, 'The Marketplace of Ideas: A Legitimizing Myth' (1984) 33(1) Duke Law Journal 1, 15; Oster, supra note 4, $21 \mathrm{f}$.

78 Compare Aristotle, Metaphysics, 1011b25, $1051 \mathrm{~b} 35$ ff; Kant, supra note 76, 102 f; Bertrand Russell, History of Western Philosophy (first published 1946, Routledge 1996), 732.

79 See, for example, VI ZR 196/08 [2009] BGHZ 181, 328, [33]; McEvoy v Michael [2014] EWHC 701 (QB), [52 ff].

80 1 BvR 221/90 [1991] BVerfGE 85, 23, 32; VI ZR 250/13 [2016] AfP 2017, 48, [14].

81 Compare McEvoy v Michael [2014] EWHC 701 (QB), [51]; Begg v BBC [2016] EWHC 2688 (QB), [53]; VI ZR 226/02 [2003] NJW 2004, 598, 599; VI ZR 204/04 [2005] NJW 2006, [17]; 1 BvR 967/05 [2007] NJW 2008, 1654, [30].

82 VI ZR 83/07 [2008] BGHZ 176, 175, [18]; VI ZR 19/08 [2009] NJW 2009, 3580, [13].

83 Compare Constantinescu v Romania App no 28871/95 (ECtHR, 27 June 2000), [73]; Einarsson $v$ Iceland App no 24703/15 (ECtHR, 7 February 2018), [50] f; Traustason and Others v Iceland App no 44081/13 (ECtHR, 4 May 2017), [48]; 1 BvR 1555/88 [1991] BVerfGE 85, 1, 19; VI ZR 252/93 [1994] NJW 1994, 2614, 2616; Case VI ZR 7/07 [2008] NJW 2008, 2110, [14]; Bukovsky v Crown Prosecution Service [2017] EWCA Civ 1529, [28].

${ }_{84}$ See only Lingens v Austria App no 9815/82 (ECtHR, 8 July 1986), [40]; Růžový panter, o.s. $v$ Czech Republic App no 20240/08 (ECtHR, 2 February 2012, [31]; OOO 'Vesti' and Ukhov v Russia App no 21724/03 (ECtHR, 7 May 2013), [63]; VI ZR 263/55 [1957] NJW 1957, 1149; Case VI ZR 7/07 [2008] NJW 2008, 2110, [15]; Jones v Skelton [1963] 1 WLR 1362, 1370; Jeynes v News Magazines Ltd and Anor [2008] EWCA Civ 130, [14]. 
in defamation will usually be unsuccessful. ${ }^{85}$ To be sure, such a statement can also tarnish a person's reputation. But it does not affect a person's good or deserved reputation. However, the gathering and dissemination of true information may violate a person's right to privacy, because the concept of 'privacy' in its subcategory 'information privacy' includes the right, at least to a certain extent, to control the release and circulation of true information about oneself. ${ }^{86}$ This includes true but confidential or intimate information, ${ }^{87}$ personal correspondence, ${ }^{88}$ photos, ${ }^{89}$ reports on criminal proceedings, ${ }^{90}$ and reportings concerning children. ${ }^{91}$ Where true information is concerned, the main - although not the only ${ }^{92}$ - question in the balancing exercise is: To what extent does the person concerned have a right to control information although it is true and, conversely, to what extent does the public have a right to receive certain information that is true but private?

By contrast, the law of defamation applies if a statement of fact turns out to be untrue, or at least if the defendant cannot prove the statement to be true. In this case, a slightly different balancing exercise applies: to what extent does the public have a right to receive the information although it is not proven true (or even proven false), and, conversely, to what extent does the person concerned have a right to control information that is not proven true (or even proven false) but of public interest? The answer to that question depends, first, on the knowledge of the publisher: if the publisher of the statement knew that the statement was false, then there is little room for freedom of expression protection, although there are quite significant differ-

85 This is at least the approach of English law, where the truth of a statement constitutes an absolute defence. One exception applies under German law: proof of truth of the asserted or disseminated fact does not exclude a claim for insult or defamation if the insult or defamation results from the form of the assertion or dissemination or the circumstances under which it was made (s 192 Criminal Law Code). The textbook example is a wedding guest who divulges true but overly salacious information about the groom's or the bride's past in a wedding speech.

86 Compare Samuel D Warren and Louis D Brandeis, 'The Right to Privacy' (1890) 4(5) Harvard Law Review 193-230; William L Prosser, 'Privacy' (1960) 48 California Law Review 383, 392; Eugene Volokh, 'Freedom of Speech and Information Privacy: The Troubling Implications of a Right to Stop People from Speaking about You' (2000) 52 Stanford Law Review 1049; Daniel J Solove, 'Conceptualizing Privacy' (2002) 90 California Law Review 1087, 1109; Daniel J Solove, 'A Taxonomy of Privacy' (2006) 154 University of Pennsylvania Law Review 477; Kirsty Hughes, 'A Behavioural Understanding of Privacy and its Implications for Privacy Law' (2012) 75 Modern Law Review 806, 809.

87 See Prince Albert v Strange [1848] 1 Mac \& G 25; Coco v AN Clark Ltd [1968] FSR 415 Ch D; Kitechnology BV and Others $v$ Unicor GmbH Plastmaschinen and Others [1995] FSR 765 (CA); Raninen v Finland App no 152/1996/771/972 (ECtHR 16 December 1997), [63]; Biriuk v Lithuania App no 23373/03 (ECtHR, 25 November 2008), [43]; 2 BvR 28/71 [1972] BVerfGE 32, 373, 379 f.

88 See ICCPR, art 17(1); ECHR, art 8(1) and German Basic Law, art 10.

89 See only Von Hannover v Germany (No 1) App no 59320/00 (ECtHR, 24 September 2004), [59]; Mosley v United Kingdom App no 48009/08 (ECtHR, 10 May 2011), [115]; National Archives and Records Administration v Favish, 124 SCt 1570 (2004).

90 See, for example, Eerikäinen and Others v Finland App no 3514/02 (ECtHR, 10 February 2009); News Verlags GmbH \& Co. KG v Austria App no 31457/96 (ECtHR, 11 January 2000); Recommendation $\operatorname{Rec}(2003) 13$ of the Committee of Ministers to member states on the provision of information through the media in relation to criminal proceedings; VI ZR 4/12 [2012] NJW 2013, 229, [15].

91 See UN Convention on the Rights of the Child, arts 16 and 40; Recommendation Rec(2003)13 of the Council of Europe on the provision of information through the media in relation to criminal proceedings, Principle 8; Kurier Zeitungsverlag and Druckerei GmbHv Austria (No 2) App no 1593/06 (ECtHR, 19 June 2012), [57]; Ageyevy v Russia App no 7075/10 (ECtHR, 26 March 2013), [175].

92 For more details, see Oster, supra note 4, $153 \mathrm{ff}$. 
ences between European approaches, on the one hand, and the case law of the US Supreme Court, on the other. ${ }^{93}$ Yet these differences are to a larger extent owed to the theoretical foundations of freedom of speech rather than perceptions of reputation.

More difficult are those statements where neither truth nor falsity could be established, and those where the publisher believed the statement to be true when issued, but which later turned out to be untrue. In these categories, the First Amendment jurisprudence of the US Supreme Court differs most significantly from the approaches taken by courts in Europe. Under First Amendment doctrine, public figures succeed in a defamation lawsuit only if they can prove that the defamatory statement was made with 'actual malice' - that is, with knowledge that it was false or with reckless disregard of whether it was false or not. ${ }^{94}$ By contrast, European courts have accepted it as principally compatible with freedom of expression to place the onus of proving the truth of defamatory statements even concerning a public figure on a defendant in libel proceedings. ${ }^{95}$ The defendant, particularly media defendants, can exonerate themselves by demonstrating that the publication was in the public interest and that they observed certain standards of diligence. ${ }^{96}$

A different set of balancing factors applies to statements of opinion. In contrast to statements of fact, a requirement to prove the truth of a value judgment is impossible to fulfil. Such a requirement would per se infringe freedom of expressing one's opinion. ${ }^{97}$ Freedom of expression protects defamatory statements of opinion if they constitute fair comment and do not overstep the boundaries of acceptable criticism. ${ }^{98}$ In this context, one has to consider whether the statement had a sufficient factual basis. ${ }^{99}$

What is the justification for distinguishing between privacy and reputation on the basis of the information concerned? Informational privacy concerns the control of factual information

93 See, on the one hand, Alithia Publishing Company Ltd and Constantinides v Cyprus App no 17550/03 (ECtHR, 22 May 2008), [67]; Pedersen and Baadsgaard $v$ Denmark App no 49017/99 (ECtHR, 19 June 2003), [78] and 1 BvR 1376/79 [1982] BVerfGE 61, 1; on the other hand, see the United States $v$ Alvarez 567 US (2012) 1, 11-15 (Kennedy J).

94 New York Times Co. v Sullivan 376 US 254, 279-80 (1964); Associated Press v Walker 389 US 28 (1967); Curtis Publishing Co. v Butts 388 US 130 (1967); Time, Inc. v Hill 385 US 374 (1967).

${ }_{95}$ McVicar $v$ the United Kingdom App no 46311/99 (ECtHR, 7 May 2002), [87]; Steel and Morris $v$ the United Kingdom App no 68416/01 (ECtHR, 15 February 2005), [93]; 1 BvR 1696/98 [2005] BVerfGE 114, 339, 353. See also Marques de Morais v Angola [2005] Communication no $1128 / 2002$ [6.8]; General Comment no 34, para 47.

96 See, for example, Defamation Act 2013, s 4; Bladet Tromsø and Stensaas v Norway App no 21980/93 (ECtHR, 20 May 1999), [66]; Karsai v Hungary App no 5380/07 (ECtHR, 1 December 2009), [32]; Kaperzyński v Poland App no 43206/07 (ECtHR, 3 July 2012), [64]; 1 BvR 456/95 [2000] NJW-RR 2000, 1209, 1211; Reynolds v Times Newspapers [2001] 2 AC 127, 205; Hourani v Thomson and Others [2017] EWHC 432 (QB), [174]. For further details, see Paul Mitchell, 'The Nature of Responsible Journalism' (2011) 3 Journal of Media Law 1; Oster, supra note 4, 183 ff.

97 See, for example, Lingens v Austria supra note 84, [46]; Ferihumer v Austria App no 30547/03 (ECtHR, 1 February 2007), [24].

98 See Defamation Act 2013, s 3; Spiller v Joseph [2010] UKSC 53, [41]; Milkovich v Lorain Journal Co. 497 US 1, 18 (1990); De Haes and Gijsels v Belgium App no 19983/92 (ECtHR, 24 February 1997), [47]; Jerusalem v Austria App no 26958/95 (ECtHR, 27 February 2001), [45]; Mustafa Erdoğan and Others $v$ Turkey App nos 346/04 and 39779/04 (ECtHR, 27 May 2014), [44]; I ZR 160/14 [2016] NJW 2016, 863 [38].

99 See only Barfod v Denmark App no 11508/85 (ECtHR, 22nd February 1989), [35]; Jalbă v Romania App no 43912/10 (ECtHR, 18 February 2014), [31]. 1 BvR 1555/88 [1991] BVerfGE 85, 1, 20; Milkovich v Lorain Journal Co. 497 US 1, 20 (1990). 
about private matters. Statements of opinion or statements of fact not proven to be true are not aspects of information privacy, either because these are not facts (but opinions) or because the person concerned denies that the stated facts relate to his or her private life, because they are untrue. In short, information privacy concerns the interest of a person about true information that should - or should not - be known about him or her; reputation concerns the interest of a person about being perceived as he or she really is. Consequently, the distribution of true statements of fact can, in principle, not constitute an illegitimate interference with a person's reputation, because a person has a right to have his or her reputation protected only insofar as the esteem by others is not based on true facts. By contrast, true statements of fact properly reflect who the person really is and may thus not be suppressed on the basis of the law of defamation, but on the basis of information privacy only. The relationship between defamation and information privacy is thus complementary. Both concern the control of information about oneself and thus help in building a reputation, albeit in different ways. Defamation and information privacy can thus be systematised as follows: information privacy applies to true but private information; defamation applies to defamatory information that is not proven true and to defamatory statements of opinion.

Drawing such a sharp and systematic distinction between defamation and information privacy is not merely an academic exercise. The gist of information privacy is the fact that certain information should never have received public attention, because the information is private. The publication as such causes a damage to the person concerned. ${ }^{100}$ A contradiction by the person concerned is useless, because there is hardly any defence against a true statement apart from 'that's none of your business'. This is different for the tort of defamation: it is the essence of defamation that certain information is untrue (or not proven true) or that defamatory opinion may cause damage to a person, because third persons might believe the information or might subscribe to the negative view of the person concerned. This means, in turn, that the negative effect of the statement might still be mitigated by counterspeech. The notion of a 'marketplace of ideas' ${ }^{101}$ is thus crucial for the application of the tort of defamation, but it has no relevance for a claim of information privacy. A distinction between defamation and information privacy based on the information concerned has thus significant doctrinal consequences: a 'right to reply' only makes sense in cases of defamation and 'false light' claims, but not against true statements of fact. ${ }^{102}$ By contrast, courts should apply injunctions more generously in cases of alleged violations of information privacy: while persons concerned might have the opportunity to correct statements of fact that are not proven true or to contradict statements of opinion, the cat is irretrievably out of the bag in the case of publications of true but private statements of fact. ${ }^{103}$

100 David Rolph, 'Irreconcilable differences? Interlocutory Injunctions for Defamation and Privacy' (2012) 17 Media and Arts Law Review 170, 190.

${ }_{101}$ Abrams $v$ the United States 250 US 616, 630 (1919) (dissenting opinion Holmes J). See also Whitney v California, 274 US 357, 375-8 (1927) (concurring opinion Brandeis J); Gertz v Robert Welch, supra note 4, 339-40; Hustler Magazine v Falwell 485 US 46, 51 (1988); $R$ v Secretary of State for the Home Department, ex p Simms [2000] 2 AC 115.

102 See, for example, AVMS Directive, art 28.

103 Compare Wizerkaniuk v Poland App no 18990/05 (ECtHR, 5 July 2011), [83]; Bonnard v Perryman [1891] 2 ch 269, 184; Paul Mitchell, The Making of the Modern Law of Defamation (Hart 2005) 91; Rolph, supra note 100. Note that because of the First Amendment, US case law is generally 
Yet it has to be asked whether this distinction is always as clearcut as suggested, or whether exceptions apply. The following two categories warrant attention: ${ }^{104}$ (1) true but defamatory statements of fact; (2) statements of fact that are not proven true but not defamatory. According to the previously developed taxonomy, true but defamatory statements of fact (category 1) do not concern a person's good or deserved reputation, but a person's privacy. This is reflected in German and English law. Under English law, the proof of (substantial) truth of a statement is an absolute defence against a defamation claim (Section 2 Defamation Act 2013). The same applies, in principle, under German law. ${ }^{105}$ Nevertheless, courts have accepted that true statements of fact which may negatively affect a person's reputation may fall under a claim of information privacy, for example, if the publication stigmatises a person or leads to social ostracism. ${ }^{106}$ In this context, German courts also speak of a 'pillory effect' ${ }^{107}$ Such an approach can also be identified in the case law of the ECtHR. ${ }^{108}$

By contrast, the suggested taxonomy of defamation and information privacy according to the information concerned seems to reveal a gap if information is being disseminated about a person that is not proven true (or even proven untrue) but not defamatory (category 2). A considerable part of tittle-tattle media consists of such examples, such as the assertion that a particular duchess is pregnant again (which she is not) or the publication of an invented but innocuous smalltalk interview with a celebrity. ${ }^{109}$ In such cases, the tort of defamation does not apply, because the information is not defamatory. According to the taxonomy of information that has just been developed, a claim for information privacy would not apply either, because the information is not true.

However, an exception from the taxonomy of information needs to apply here. Leaving untrue but not defamatory statements of fact without legal consequences would be unjustified with a view to both the reproachable behaviour of the publisher and the legitimate interest of the person concerned 'not to have lies told about him' or her. ${ }^{110}$ As a result, the right to information privacy should be conceptualised in such a way that it would also cover untrue but not defamatory information if the information concerns a person's private life. That should be the case if, in the words of William L. Prosser's seminal 1960 article on privacy, the publication leads to a 'publicity which places the plaintiff in a false light in the public eye'. ${ }^{111}$ Accepting such a 'false light' claim under information privacy is justified, because information privacy at least to a certain extent - also encompasses the right to decide whether or not a person wants

opposed to injunctions: Near v Minnesota 283 US 697, 713 (1931); Bantam Books, Inc. v Sullivan 372 US 58, 70 (1963); New York Times Co. $v$ the United States 403 US 713, 714 (1971).

${ }_{104}$ Compare John Terry (previously referred to as 'LNS') v Persons Unknown [2010] EWHC 119 (QB), [96]; Eric Barendt, ‘An Overlap of Defamation and Privacy?' (2015) 7 Journal of Media Law 85.

${ }_{105} 1$ BvR 131/96 [1998] BVerfGE 97, 391, 403; VI ZR 243/08 [2010] NJW 2010, 2432, [16]. The exception is s 192 Criminal Law Code (supra note 85 ).

106 VI ZR 332/09 [2011] NJW 2012, 767, [25]; 1 BvR 131/96 [1998] BVerfGE 97, 391, 405.

107 In German 'Prangerwirkung'; see 1 BvR 536/72 [1973] BVerfGE 35, 202, 233; 1 BvR 2126/93 [1999] NJW 1999, 2358, 2359.

108 Compare Biriuk v Lithuania supra note 87, [41]; Ageyevy v Russia supra note 91, [216].

109 On the latter, see Prosser, supra note 86, 398 f; 1 BvR 112/65 [1973] BVerfGE 34, 269, 283 f; 1

BvR 185/77 [1980] BVerfGE 54, 148, 155.

110 See Silkin v Beaverbrook Newspapers Ltd [1958] 1 WLR 743, 746 (QB) (Diplock J).

111 Prosser, supra note 86, 400. 
to be in public. ${ }^{112}$ In addition, information privacy should be applied to statements that are not proven true but not defamatory in cases in which publications about children are involved. ${ }^{113}$

With a view to the taxonomy of the information concerned, defamation and information privacy are thus to be conceptualised as follows:

(1) The tort of defamation applies to

(a) untrue or not proven true statements of fact

(b) and statements of opinion,

if the statement of fact or of opinion is defamatory.

(2) Information privacy applies to

(a) true statements of fact that unjustifiably reveal private information

(b) and to statements of fact that are untrue or not proven true that either stigmatise a person or that place the person concerned in a false light in the public eye.

\section{REPUTATION AND DATA PROTECTION}

Violations of reputation (and information privacy) presuppose the communication of information. 'Information' is data with a particular meaning. ${ }^{114}$ The tort of defamation relates to information only in its semantic dimension, that is, with a view to its meaning, in this case its defamatory meaning. By contrast, the syntactic dimension of information, that is, its codification as data, is irrelevant for the tort of defamation. The approach of data protection law is diametrically opposed. The reference point for data protection is the codification of certain information as data, more precisely, as personal data. By contrast, the semantic dimension of personal data - the data's meaning - is, in principle, irrelevant for the application of data protection law. Nevertheless, such data can have a defamatory meaning.

Article 8 Charter of Fundamental Rights of the European Union and Article 16 General Data Protection Regulation (GDPR) provide a right to have inaccurate personal data 'rectified'. ${ }^{115}$ Inaccurate data is, in its semantic dimension, a false statement of fact, which lies at the heart of the tort of defamation. Although 'inaccurate' data does not necessarily have to be defamatory, it can be defamatory. Since EU data protection rules apply not only to public but also to private data processors, ${ }^{116}$ the rights provided by data protection law may thus also serve as a remedy against defamation. And even if the data is not proven inaccurate or even proven accurate,

112 Compare 1 BvR 185/77 [1980] BVerfGE 54, 148, 155; McKennitt v Ash [2006] EWCA Civ 1714, [80] (Buxton LJ), [86] Longmore LJ.

${ }_{113}$ Compare KU Finland App no 2872/02 (ECtHR, 2 December 2008), [41].

114 Luciano Floridi, The Philosophy of Information (OUP 2011), 83.

115 Charter of Fundamental Rights of the European Union, OJ C 202, 7.6.2016, 389-405; Regulation (EU) 2016/679 of the European Parliament and of the Council of 27 April 2016 on the protection of natural persons with regard to the processing of personal data and on the free movement of such data, and repealing Directive 95/46/EC. See also Ciubotaru v Moldova App no 27138/04 (ECtHR, 27 April 2010); Cemalettin Canl $v$ Turkey App no 22427/04 (ECtHR, 21 October 2008); Khelili v Switzerland App no 16188/07 (ECtHR, 18 October 2011).

116 This is expressly stated in GDPR, Recitals 5, 6, 19, 97, 122, 128 and 158, and this is also how CFR, art 8(2) should be read: as a fundamental right with direct horizontal effect (Oster, supra note 4, 32). 
the notorious 'right to be forgotten' according to Article 17 GDPR may apply if, among other things, the data is 'unnecessary'. ${ }^{117}$

Data protection law as an instrument to vindicate alleged violations of a person's reputation (or information privacy) has several advantages over the tort of defamation and privacy claims. Data protection law operates ex officio, that is, a supervisory authority has to intervene if it learns of a violation of data protection rules (Articles $51 \mathrm{ff}$ GDPR). Instead of having to sue the defendant himself or herself, the claimant may thus notify the supervisory authority and leave the enforcement of data protection law in their hands. ${ }^{118}$ Moreover, data protection law furnishes the data subject with considerable damages claims, ${ }^{119}$ supported by information rights and rights of access to information. ${ }^{120}$ Therefore, with a view to digitisation and datafication of information, data protection law plays an increasingly important role also for the protection of reputation, particularly in the EU. ${ }^{121}$

\section{CONCLUSION}

The lack of consensus regarding the protection of reputation as a limitation to free speech, even among liberal democracies, maintains a fragmentation of legal regimes for transnational and international communication. This contribution examined the theoretical foundations of reputation. It has become clear that theories on reputation can explain certain aspects of defamation doctrine, but no single theory can provide an all-encompassing explanation. The contribution has demonstrated that two ideal-types of reputation theory - named 'reputation as dignity' and 'reputation as property' - account for the differences between the jurisdictions under investigation.

As an alternative approach, this contribution has suggested conceptualising reputation and its distinction from information privacy with a view to the information concerned. This reflects the notion of reputation as a right to control information about oneself. The perspective from information provides the gateway to data protection law, which can be presumed to have an increasingly important function for the protection of both reputation and privacy in a time of digitisation and datafication.

117 See Case C-131/12 [2014] Google Spain SL and Google, Inc. v Agencia Española de Protección de Datos (AEPD) and Mario Costeja González ECLI:EU:C:2014:317.

118 As was the case in Google v AEPD, ibid.

119 Art $77 \mathrm{ff}$ GDPR; Google, Inc. v Vidal-Hall and Others [2015] EWCA Civ 311.

120 See CFR, art 8(2); GDPR, arts 14 and 15; Case C-553/07 [2009] College van burgemeester en wethouders van Rotterdam v MEE Rijkeboer ECLI:EU:C:2009:293; Leander v Sweden App no 9248/81 (ECtHR, 26 March 1987), [48]; Gaskin v the United Kingdom App no 10454/83 (ECtHR, 7 July 1989), [49]; KH and Others $v$ Slovakia App no 32881/04 (ECtHR, 28 April 2009), [50].

${ }_{121}$ See, for example, HH Prince Moulay Hicham Ben Abdallah Al Alaoui of Morocco v Elaph Publishing Ltd [2017] EWCA Civ 29, [43 f]. 